\title{
A Model of Horizontal and Vertical Allocation of Eco-Compensation Responsibility Among Administrative Areas: A Study Based on Ecosystem Services Value Density
}

\author{
Zhou Lixuan ${ }^{1,2,3, *}$, Peng Xiaochun ${ }^{2}$, Song Weiwei ${ }^{2}$, Yu xijun ${ }^{2}$, Zeng Siyuan², Wang Juanjuan ${ }^{2}$ and \\ Fang Qiaoli ${ }^{2}$
}

${ }^{1}$ Guangzhou Institute of Geochemistry, Chinese Academy of Sciences, Guangzhou 510640; ${ }^{2}$ South China Institute of Environmental Sciences, Ministry of Environmental Protection, Guangzhou 510655; ${ }^{3}$ University of Chinese Academy of Sciences, Beijing 100049

\begin{abstract}
The implementation of eco-compensation schemes demands large capital investment. Therefore, the raising and allocation of funds is critical to the smooth operation of an eco-compensation mechanism. However, the majority of studies on eco-compensation dwell on the development of compensation standards and the allocation of compensation funds, with very few studies considering the allocation of compensation responsibility among multiple compensation providers. Choosing Zhongshan as a case, this paper explores how to reasonably allocate the responsibility among the compensation providers in case of a demand for larger compensation due to any changes in the eco-compensation standards, so as to successfully raise the required funds for compensation. In accordance with the "Beneficiary Pays Principle", and for the purpose of ensuring the successful raising of the compensation funds, this paper constructs a model comprising three ecocompensation providers, including the provincial and municipal government as well as the towns receiving the spillover effect of ecosystem services provided by other townships. After analyzing the spatial distribution of ecosystem services, it further builds a model of compensation responsibility allocation (CRA) among townships in connection with regional ecosystem services value density and the gap between demand and supply of ecosystem service value. At the end, the paper simulates the results of CRA among the three eco-compensation providers in Zhongshan under five scenarios.
\end{abstract}

Keywords: Compensation responsibility allocation, eco-compensation, ecological value density, horizontal and vertical compensation.

\section{INTRODUCTION}

The eco-compensation issue has always been a matter of close attention and concern. In 2010, the State Council of the People's Republic of China put the research and formulation of the regulations on eco-compensation on its legislative agenda. Moreover, the Report of the Eighteenth National Congress of the Communist Party of China explicitly directed the relevant entity to establish a system for paying for resource consumption and compensating for ecological damage - a system that responds to market supply and demand and resource scarcity, recognizes ecological values and requires compensation in the interests of later generations. Serving as a systematic economic means, the ecocompensation mechanism aims to regulate the environmental and economic interests allocation among shareholders relevant to eco-environment protection [1] to further encourage the relevant parties to build and protect the eco-environment, as well as to maintain and utilize ecosystem services in a sustainable way. However, the implementation of ecocompensation schemes demands a large amount of financial investment, which invariably means that fundraising is critical to the smooth operation of an eco-compensation mechanism [2]. Eco-compensation is not a "silver bullet" which can be used as a powerful cure for some particular environmental problems rather than a cure for all. The effectiveness and efficiency of eco-compensation primarily depend on program design [3], and a good eco-compensation mechanism should be able to raise and allocate funds in an effective way [4]. It follows that a scientific and reasonable design of the mechanism determines whether or not an ecocompensation policy can be implemented effectively.

With regard to the selection of eco-compensation models, inter-regional eco-compensation, under most circumstances, prefers to adopt vertical compensation involving the higherlevel government [5]. The compensation models applied in Beijing and Tianjin Sandstorm Source Region [6] and Dongjiang Riverhead Region [7] are good examples in this regard. The addressing of spillover effects of ecosystem services (SEES) from one region to another still needs to take into account the horizontal eco-compensation [8]. The studies on the Jiulong River watershed [9], Beijing-Hebei water source [10], Xin'an River watershed [11] and the Sanjiangyuan region [12], among others, have all adopted the horizontal compensation model where, however, transfer payment is 
made horizontally from one party to another without involving multiple compensation providers. Some scholars also propose a combination of the horizontal and vertical ecocompensation models [13]. Nonetheless, the vertical compensation led by the higher-level governmental authorities dominates the overall scenario of eco-compensation in China, where cross-regional vertical compensation is performed less frequently.

Quantitative examination of eco-compensation has always been the focal point for research in this field and recent studies have mainly focused on the compensation standards. The game theory model proposed by Cao Guohua et al. [14], the compensation standard model based on water environmental capacity by Pang Aiping et al. [15], the compensation standard model based on water quality and total pollutant volume by Lu Yan et al. [16], the compensation standard model based on pollutant treatment level by $\mathrm{Fu}$ Yicheng et al. [17], and the model of allocating eco-compensation amount based on improved Shapley value by Li Weiqian et al. [18], have all explored the methods for calculating ecocompensation in water basins and the relevant standards. Researchers have also examined interregional ecocompensation standards by employing the ecological value equivalent [19], loss of development opportunity [20], carbon balance [21], and other approaches respectively. However, few quantitative studies exist in respect of the allocation of compensation responsibility among multiple compensation providers.

Quantitative methods are employed, on a frequent basis, in the studies on eco-compensation providers and receivers. Babcock et al. [22]. examined the compensation receivers' spatial choices by introducing three approaches that target benefits, costs, and benefit-to-cost ratios. Powell et al. [23]. identified the priority zones for protection of biodiversity and the compensation receivers by applying the benefit targeting approach and GAP analysis. Ferrsro et al. [24]. identified the priority zones for biodiversity and watershed protection as well as the priority compensation receivers by employing the benefit-to-cost ratio approach. Further, Chomitz et al. [25]. selected the participants in eco-compensation and prepared an eco-compensation scheme with low cost and high environmental efficiency. It can be concluded that selecting eco-compensation receivers through quantitative study may help to raise eco-compensation efficiency. Additionally, Wang Nvjie et al. [26], Zhong Juntao et al. [27], Sun Xianbin et al. [28] and Zhang Meng et al. [29] assessed the eco-compensation priorities among regions based on the ecosystem services value and further identified the ecocompensation providers and receivers within a province or economic circle; Jin Yanming et al. [30] identified the ecocompensation receivers in the West-East Power Transmission Project by applying the computable general equilibrium model for three regions (Guizhou Province, Guangdong Province, and other areas in the Chinese mainland); Gong Fang [31] identified the grassland ecological compensation providers through the analysis paradigm for shareholders, and further constructed "the model of four compensation providers for grassland ecology". However, she failed to address the allocation of compensation responsibility among the four compensation providers. To sum up, the studies on eco-compensation providers and receivers, home and abroad, primarily center on questions such as "who should compensate whom" and "how much compensation should the receivers get", thus ignoring the research on compensation amount which should be paid by the compensation providers and the allocation of responsibility among multiple compensation providers.

The statistics compiled by Dai Qiwen show that, among all the research papers concerning eco-compensation published in the leading Chinese journals since the 1980s, the papers dedicated to the topic of eco-compensation providers account for merely $0.3 \%,[32]$ and those on the quantitative study on the allocation of compensation responsibility among multiple compensation providers have not been found. Therefore, selecting Zhongshan as a case for study, this paper, in line with the "Beneficiary Pays Principle", attempts to construct a vertical and horizontal ecocompensation model comprising three eco-compensation providers at the provincial, municipal and township levels respectively. Based on this, the paper, after reviewing the uneven distribution of ecosystem services value among regions and the spillover effect of ecosystem services, also endeavors to build a model for horizontal allocation of ecocompensation responsibility among townships, and to simulate the results of responsibility allocation among the three eco-compensation providers under different scenarios.

\section{INTRODUCTION TO THE REGION UNDER STUDY}

Located in the south central part of Guangdong Province, Zhongshan is a typical hinterland city in the Pearl River Delta region. Farmland and forest eco-compensation schemes have been implemented in Zhongshan. On one hand, $735,700 \mathrm{mu}$ of farmland in the city is covered by the farmland eco-compensation scheme and the compensation is provided at the rate of 50 Yuan/year $\bullet$ mu. The fund for farmland eco-compensation is $36,785,000$ Yuan in total which is shared by the provincial and municipal authorities. To be specific, the provincial government pay their share at the rate of 15 Yuan/year $\bullet$ mu, and the remaining amount (35 Yuan/year-mu) is paid by the municipal government. On the other hand, 229,700 mu of provincial non-commercial forest and $184,700 \mathrm{mu}$ of municipal non-commercial forest in the city are covered by the forest eco-compensation scheme and the compensation is provided at the rate of 48 Yuan/year $\bullet m u$. The fund for forest eco-compensation is 19,891,200 Yuan in total. The eco-compensation fund for provincial noncommercial forest is shared equally by provincial and municipal authorities and the eco-compensation fund for municipal non-commercial forest is paid by the municipal authorities and the relevant towns in the ratio of 4:6.

Five problems have been found in the existing ecocompensation schemes in Zhongshan. First, in accordance with the "Beneficiary Pays Principle", the current ecocompensation providers are not fully included. These schemes fail to include all the parties enjoying the SEES. Second, the fact that the townships receiving compensation provide supporting funds violates the "Protector Receives Principle" and hence raises the fiscal burden of such townships, which further influences the effectiveness of ecocompensation policies. Third, the existing compensation 
Table 1. Compensation fund in Zhongshan when adjusting eco-compensation standard.

\begin{tabular}{|c|c|c|c|c|c|c|c|c|}
\hline \multirow{2}{*}{\multicolumn{2}{|c|}{ Compensation Object }} & \multirow{3}{*}{$\begin{array}{c}\begin{array}{c}\text { Area } \\
(\mathbf{m u})\end{array} \\
229,700\end{array}$} & \multicolumn{4}{|c|}{ Compensation Standard (Yuan/year•mu) } & \multicolumn{2}{|c|}{ Compensation Fund (Yuan) } \\
\hline & & & \multirow{2}{*}{$\frac{\text { Current }}{48}$} & \multirow{2}{*}{$\frac{\text { Public's WTP }}{97.7}$} & \multirow{2}{*}{$\begin{array}{c}\text { Township's WTP } \\
243.7\end{array}$} & \multirow{2}{*}{$\begin{array}{c}\text { Proposed } \\
80\end{array}$} & \multirow{2}{*}{$\begin{array}{c}\text { Before } \\
11,025,600\end{array}$} & \multirow{2}{*}{$\begin{array}{c}\text { After } \\
18,376,000\end{array}$} \\
\hline Forect & Provincial & & & & & & & \\
\hline & Municipal & 184,700 & 48 & 97.7 & 243.7 & 80 & $8,865,600$ & $14,776,000$ \\
\hline \multicolumn{2}{|c|}{ Forest } & 735,700 & 50 & 342.3 & 262 & 100 & $36,785,000$ & $73,570,000$ \\
\hline \multicolumn{2}{|c|}{ Total } & - & - & - & - & - & $56,676,200$ & $106,722,000$ \\
\hline
\end{tabular}

Table 2. Responsibility of regional eco-compensation providers.

\begin{tabular}{|c|c|c|}
\hline Eco-compensation Provider & Compensation Responsibility & Responsibility Mount \\
\hline \hline Provincial government & SEES provided by city & Value of SEES provided by city \\
\hline Municipal government & shared ecosystem services within city & Value of shared ecosystem services within city \\
\hline Townships get the SEES & SEES received & Value of SEES received \\
\hline
\end{tabular}

model fails to reflect the spillover of ecosystem services from one township to another and the uneven distribution of responsibility to protect the ecological environment. Fourth, in the existing fundraising model, the total amount of the eco-compensation fund is largely restricted by the municipal government' capacity to pay. Fifth, the existing ecocompensation standard is relatively low, which has discouraged the relevant parties from protecting the ecology. Nevertheless, higher compensation standard will create greater fundraising burden. If public and towns' opinions regarding the adjustments to the eco-compensation standards are taken into account, the total amount in the eco-compensation fund for the entire Zhongshan shall be twice as much as the original one as shown in Table $\mathbf{1}$.

\section{STUDY ON THE MODEL}

The eco-compensation fundraising model shall be established in this study in two steps: the first is to define the scope of eco-compensation providers after specifying the beneficiaries of ecosystem services; the second is to construct a model for the allocation of responsibility among compensation providers based on the value generated by SEES acquired by such providers.

\subsection{Study on Eco-compensation Providers}

The "misplacement" of right holders and obligation assumers in respect of regional eco-compensation constitutes a big challenge which should be addressed when we conduct any research on regional eco-compensations. Nevertheless, the question "who should compensate whom" is rarely touched in the existing studies [27]. Currently, ecocompensation providers in Zhongshan consist of provincial and municipal government together with township government possessing non-commercial forests, excluding townships receiving SEES. However, as a matter of fact, part of the townships owning non-commercial forests are providers of ecosystem services producing spillover effects and should be considered as compensation receivers. Under the circum- stance of uneven distribution of ecosystem services, a demand and supply relationship exists between townships regarding the value generated by SEES. In accordance with the "Beneficiary Pays Principle", the townships enjoying the SEES should pay some eco-compensation.

In conclusion, the eco-compensation providers in the municipal administrative areas should include the provincial and municipal government together with towns receiving SEES. Specifically, the provincial government should pay the compensation for SEES provided within the municipal administrative area, the municipal government should assume the compensation for shared ecosystem services within the municipal administrative area, and the towns should pay the one for the SEES received as shown in Table 2.

\subsection{Model Construction}

As indicated in Table 3, the township whose density of ecosystem services value is higher than or equivalent to the city's average density provides SEES, and its coefficient of allocation of eco-compensation responsibility(CAECR) is zero; the township whose density of ecosystem services value is lower than the city's average density will receive SEES, and should accordingly assume compensation responsibility based on the SEES received by it. CAECR of township should be calculated in accordance with Formula (1), that is, CAECR in a township falling within the category of compensation provider is equivalent to the gap between demand and supply of ecosystem services value in that township divided by the total gap between demand and supply of ecosystem services value in all the townships across the city; and the coefficient of allocation of eco-compensation responsibility in a township falling within the category of compensation receiver is zero.

$$
\begin{aligned}
t_{i} & =\frac{A_{i}\left(F-f_{i}\right)}{\sum A_{i}\left(F-f_{i}\right)}\left(\text { iff }_{i} \geq F\right) \\
t_{i} & =0\left(\text { iff }_{i} \geq F\right)
\end{aligned}
$$


Table 4. Equivalent value per unit area of ecosystem services in Zhongshan by land type unit: yuan/ha/a.

\begin{tabular}{|c|c|c|c|c|c|c|c|}
\hline Category & Forest & Grassland & Farmland & Wetland & Water Body & $\begin{array}{c}\text { Land for } \\
\text { Construction }\end{array}$ & Bare Land \\
\hline \hline Food production & 136.10 & 177.34 & 412.43 & 148.48 & 218.59 & 0 & 8.25 \\
\hline Raw material production & 1229.04 & 148.48 & 160.85 & 98.98 & 144.36 & 0 & 16.49 \\
\hline Gas regulation & 1781.70 & 618.65 & 296.95 & 993.96 & 210.34 & 0 & 24.75 \\
\hline Climate regulation & 1678.59 & 643.39 & 400.06 & 5588.43 & 849.61 & 0 & 53.61 \\
\hline Hydrological regulation & 1686.84 & 626.89 & 317.57 & 5543.06 & 7741.31 & 0 & 28.87 \\
\hline Waste treatment & 709.38 & 544.41 & 573.28 & 5938.99 & 6124.59 & 0 & 107.24 \\
\hline Soil conservation & 1657.97 & 923.84 & 606.27 & 820.74 & 169.10 & 0 & 70.12 \\
\hline Biodiversity maintenance & 1860.06 & 771.25 & 420.68 & 1521.87 & 1414.63 & 0 & 164.97 \\
\hline Providing aesthetic & 857.86 & 358.82 & 70.12 & 1934.30 & 1831.19 & 0 \\
\hline Total & 11597.53 & 4813.06 & 3258.20 & 22588.79 & 18703.71 & 98.98 \\
\hline
\end{tabular}

where, $\mathrm{t}_{\mathrm{i}}$ indicates the CAECR in the $i$-th township; ${ }_{\mathrm{i}}$ indicates the density of the ecosystem services value in the $i$-th township; indicates the density of the ecosystem services value in the whole city; $A_{i}$ indicates the total administrative area of the $i$-th township.

The density of the township ecosystem services value should be calculated in accordance with Formula (2), which should be equivalent to the total ecosystem services value in the township divided by the total area of the township.

$$
f_{i}=\frac{\sum\left(k_{1} a_{i 1}+k_{2} a_{i 2}+\ldots+k_{n} a_{n}\right)}{A_{i}}
$$

where, indicates the area of the $n$-th land type in the $i$-th township; indicates the ecosystem services value of the $n$-th land type per unit area.

The amount of eco-compensation payable by the township falling within the category of compensation provider should be calculated in accordance with Formula (3), which should be equivalent to the CAECR of township multiplied by the total amount of eco-compensation fund borne by the township.

$$
D_{i}=t_{i} \times D
$$

where, indicates the eco-compensation fund payable by the $i$ th township; indicates the total amount of eco-compensation fund borne by the township.

\subsection{Study on the Ecosystem Services Value Based on Dif- ferent Land Types in Zhongshan}

Notwithstanding that the 17 ecosystem functions asserted by Costanza et al. [33] have covered its main functions, and a great majority of researchers have conducted their own studies based on such an assertion, Costanza's value coefficient fails to fit and be relevant to the terrestrial ecosystem in China. Xie Gaodi et al. [34] have developed a table for the coefficient of value of terrestrial ecosystem services in China. Thus far, a considerable number of studies concern- ing the terrestrial ecosystem services value in China have employed the value coefficient proposed by Xie Gaodi.

Considering the "equivalent value per unit area of terrestrial ecosystem services in China by land type" proposed by Xie Gaodi et al. [35] and the fact that the economic value of ecosystem services per unit area in China in 2005 is equivalent to 449.1 Yuan/ha, this paper attempts to define the ecosystem services value coefficient in line with the development and land use features of Zhongshan, based on the economic value of food production in farmland per unit area.

Zhongshan Statistical Yearbook, 2006, reveals that the grain yield per unit area of arable land in Zhongshan, in 2005, reached $5,415 \mathrm{~kg} / \mathrm{ha}$, whereas Cost and Income of Chinese Farm Produce shows that the average grain yield per unit area of arable land in China, for the same period, was $5,896.50 \mathrm{~kg} / \mathrm{ha}$. Accordingly, we find that the equivalent value per unit area of ecosystem services in Zhongshan is 412.43 Yuan/ha, after correcting the coefficient of the equivalent value of ecosystem services in China [36]. By referring to the studies of Chen Lin et al. [37] and Zeng Jie et al. [36], this paper assumes that the equivalent values per unit area of ecosystem services by land type stay the same in different years. Hence, the equivalent value per unit area of ecosystem services in Zhongshan by land type is stated in Table 4, where the values of forest and farmland ecosystem services per unit area are 11,597.53 Yuan/ha/a and 3,258.20 Yuan/ha/a, respectively.

\subsection{Calculation of CAECR of Township}

In accordance with Formulas (1) and (2), considering the equivalent values of forest and farmland ecosystem services per unit area in Zhongshan, the area of forest and farmland in each township as well as the total administrative area of a township, we calculated the ecosystem services value density, the gap between demand and supply of ecosystem services value, and the CAECR in each township (see Table 5). Our calculations indicate that the ecosystem services value density in 8 townships, such as Wuguishan Town, is higher than the city's average density. Such 8 townships are not 
Table 5. Township ecosystem services value density and CAECR.

\begin{tabular}{|c|c|c|c|c|c|c|}
\hline \multirow{3}{*}{ Township } & \multicolumn{3}{|c|}{ Area } & \multicolumn{2}{|c|}{ Ecosystem Services Value } & \multirow{2}{*}{ CAECR } \\
\hline & Forest & Farmland & Township & Density & Gap & \\
\hline & mu & mu & ha & Yuan/ha & Yuan & Dimensionless \\
\hline Wuguishan & 91119.0 & 5217 & 10122.7 & 7,072 & 0 & 0 \\
\hline Sanxiang & 62481.0 & 16554 & 9361.21 & 5,545 & 0 & 0 \\
\hline Nanqu & 32044.5 & 5614 & 4721.19 & 5,506 & 0 & 0 \\
\hline Dongqu & 46351.5 & 1191 & 7319.69 & 4,931 & 0 & 0 \\
\hline Nanlang & 78819.0 & 34365 & 15247.38 & 4,486 & 0 & 0 \\
\hline Shenwan & 24477.0 & 26507 & 6092.98 & 4,051 & 0 & 0 \\
\hline Banfu & 28551.0 & 44704 & 7969.67 & 3,988 & 0 & 0 \\
\hline Tanzhou & 27174.0 & 85917 & 12957.91 & 3,062 & 0 & 0 \\
\hline Dachong & 4399.5 & 23231 & 4066.01 & 2,078 & $2,935,659$ & 0.020 \\
\hline Minzhong & 0 & 104086 & 12186.57 & 1,855 & $11,516,309$ & 0.080 \\
\hline Sanjiao & 477.0 & 55026 & 7012.92 & 1,757 & $7,314,476$ & 0.051 \\
\hline Fusha & 0 & 26911 & 3540.53 & 1,651 & $4,068,069$ & 0.028 \\
\hline Huangpu & 1956.0 & 58981 & 8834.81 & 1,621 & $10,416,241$ & 0.073 \\
\hline Henglan & 0 & 55291 & 7573.76 & 1,586 & $9,194,545$ & 0.064 \\
\hline Huo Ju & 15775.5 & 5038 & 9234.75 & 1,439 & $12,568,495$ & 0.088 \\
\hline Shaxi & 0 & 34231 & 5240.1 & 1,419 & $7,236,578$ & 0.050 \\
\hline Dongsheng & 0 & 45325 & 7533.38 & 1,307 & $11,247,336$ & 0.078 \\
\hline Gangkou & 0 & 41919 & 7127.37 & 1,278 & $10,847,857$ & 0.075 \\
\hline Dongfeng & 0 & 25109 & 5624.43 & 970 & $10,292,707$ & 0.072 \\
\hline Guzhen & 0 & 17100 & 5220.9 & 711 & $10,906,460$ & 0.076 \\
\hline Xiaolan & 0 & 15486 & 7195.99 & 467 & $16,788,245$ & 0.117 \\
\hline Shiqi & 780.0 & 1379 & 2257.66 & 400 & $5,418,384$ & 0.038 \\
\hline Xiqu & 0 & 4354 & 2517.88 & 376 & $6,103,341$ & 0.043 \\
\hline Nantou & 0 & 2130 & 2574.71 & 180 & $6,745,740$ & 0.047 \\
\hline Total city & 414405 & 735666 & 171534.5 & 2,800 & - & - \\
\hline
\end{tabular}

required to pay eco-compensation as they provide ecosystem services producing spillover effects. In contrast, the ecosystem services value density in 16 townships, including Dachong, is lower than the city's average density, showing a gap between supply and demand. Falling within the category of eco-compensation providers, these 16 townships should pay eco-compensation because they enjoy spillover effects from ecosystem services provided by other townships. Among those townships, Xiaolan, Huoju and Minzhong should shoulder the heaviest eco-compensation responsibility. The eco-compensation responsibility assumed by such three townships accounts for $28.5 \%$ of the total amount by all townships in the city, while the eco-compensation responsibility borne by Dochong or each of the other four townships is less than $5 \%$ of the total amount. In this sense, the latter has a lesser burden to pay eco-compensation.

\section{SCENARIO SIMULATION}

\subsection{Scenario Design}

The amount payable to the forest and farmland ecocompensation fund by the provincial government is appropriated in line with the relevant standard promulgated by the provincial. Consequently, we assume that the total amount of eco-compensation appropriated by the provincial government remains constant. Based on this assumption, we figure out the amount payable to the eco-compensation fund by each compensation provider under different models of re- 
Table 6. Scenario design for eco-compensation fund raising in Zhongshan.

\begin{tabular}{|c|c|c|}
\hline Scenario & Municipal Government & Township Government \\
\hline \hline Scenario 1 & stay the same & $80 \%$ of ECFJCMT s \\
\hline Scenario 2 & $20 \%$ of ECFJCMT & $60 \%$ of ECFJCMT \\
\hline Scenario 3 & $40 \%$ of ECFJCMT & $40 \%$ of ECFJCMT \\
\hline Scenario 4 & $60 \%$ ECFJCMT & $20 \%$ of ECFJCMT \\
\hline Scenario 5 & $80 \%$ ECFJCMT \\
\hline
\end{tabular}

*ECFJCMT means the eco-compensation fund jointly contributed by the municipal and towns

sponsibility allocation between municipal and township government. Five scenarios are included in this design: Scenario 1 represents the newly increased funds generated by any changes to the standard for calculating funds payable by the towns, when the funds payable by the municipal authorities stay the same; Scenario 2 represents the amount of the ecocompensation fund payable by the municipal and towns, respectively, in the ratio of $2: 8$, excluding the part payable by the provincial government; Scenario 3 represents the amount of the eco-compensation fund payable by the municipal and towns, respectively, in the ratio of $4: 6$, excluding the part payable by the provincial government; Scenario 4 represents the amount of the eco-compensation fund payable by the municipal and towns, respectively, in the ratio of $6: 4$, excluding the part payable by the provincial government; and Scenario 5 represents the amount of the ecocompensation fund payable by the municipal and towns, respectively, in the ratio of $8: 2$, excluding the part payable by the provincial government.

\subsection{Scenario Simulation}

As shown in Table 6 we calculated the amount of the eco-compensation fund payable by the provincial, municipal and township government under five scenarios, together with the amount payable by 16 townships falling within the category of compensation providers. Our calculations show that under Scenario 3, where the payment proportion between the municipal and towns is consistent with the current conventional practice in this regard in Zhongshan, the municipal authorities should pay an amount of 36,069,480 Yuan towards the eco-compensation fund and the 16 townships falling within the category of eco-compensation providers should pay a total of 54,104,220 Yuan. Among these townships, Xiaolan Town, the heaviest responsibility bearer, should pay 6,325,340 Yuan, while the lightest responsibility bearer, Dachong Town, should pay 1,104,430 Yuan. Considering the relatively small administrative area of Zhongshan, and the frequent activities conducted across townships within the city, we contend that shared ecosystem services within the city are far more than those producing spillover effects and, therefore, Scenario 5 fits the actual situation to a greater extent. However, the specific proportion of ecocompensation responsibility taken by the municipal and towns may be determined only after a further examination of the reception of ecosystem services value within the city as shown in Table 7.

\section{CONCLUSION}

Existing studies primarily focus on exploring questions such as "who should compensate whom" and "how much compensation should the receivers get", ignoring the research on the compensation amount which should be paid by the compensation providers and the allocation of responsibility among multiple compensation providers. Therefore, selecting Zhongshan as a case for study, this paper, after identifying the parties receiving ecosystem services value, constructed a model comprising three eco-compensation providers at the provincial, municipal and township levels respectively. Based on it, this paper, after reviewing the uneven distribution of ecosystem services value among different regions and the spillover effect of ecosystem services, further builds a model for horizontal allocation of ecocompensation responsibility among townships falling within the category of compensation providers, and simulates the results of responsibility allocation among the three ecocompensation providers under different scenarios.

The following conclusions are drawn from this study:

1. The eco-compensation providers should be identified in line with the "Beneficiary Pays Principle". In this regard, the eco-compensation providers within the city should include the provincial and municipal government, as well as the towns receiving SEES. And these three providers should pay the compensation for the SEES provided within the city, for shared ecosystem services within the city, and for SEES from one township to another.

2. The spillover of ecosystem services from one township to another is caused by the uneven distribution of ecosystem services value. The township with a low density of ecosystem services value and receiving the SEES provided by other townships should be a compensation provider, and should assume the responsibility to pay the compensation for the spillover effect of ecosystem services received by it.

3. The CAECR for a township falling within the category of compensation provider depends on the ratio that the gap between demand and supply of ecosystem services value in that township accounts for in the total gap between 
Table 7. Scenarios for eco-compensation fund raising under different fundraising models.

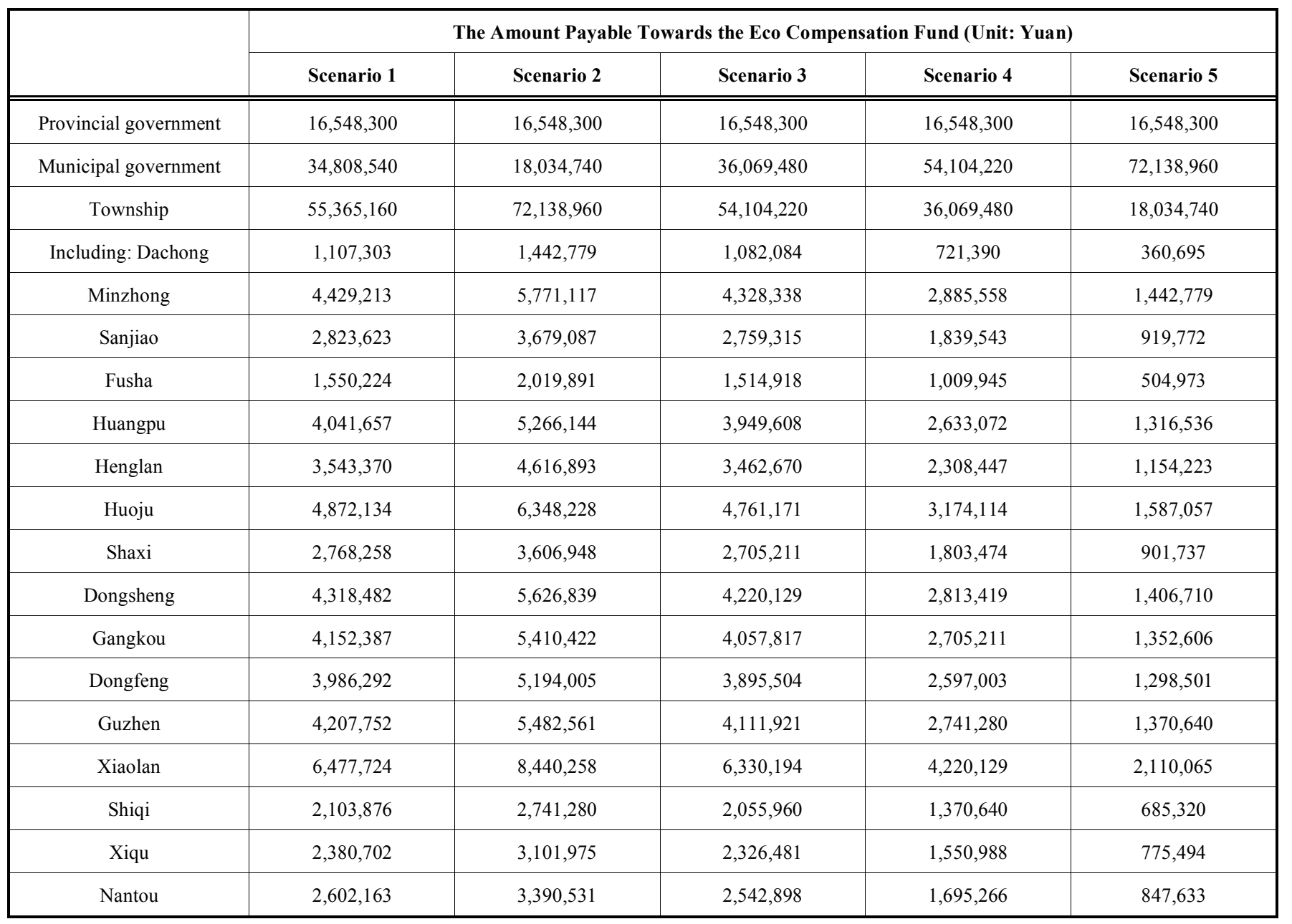

demand and supply in all the townships across the city. For a township falling within the category of compensation receiver, the CAECR is zero. The amount payable towards the eco-compensation fund by a township falling within the category of compensation provider is determined by two factors - its CAECR and the total amount payable towards the eco-compensation fund shared by all the townships.

4. Facing the difficulty to quantify the shared ecosystem services value within the city and the value generated from the SEES among townships, this paper has worked out five scenarios with regards to responsibility allocation between municipal and township government, and simulated the results of eco-CRA among provincial, municipal and towns. Among these scenarios, Scenario 3 most closely resembles the model of shared contribution towards the eco-compensation fund by municipal and towns currently effective in Zhongshan. Nevertheless, considering the frequent activities conducted across townships within the city, we assert that Scenario 5 may fit the actual situation to a greater extent.

5. Since the current eco-compensation schemes in Zhongshan merely cover forests and farmlands, we only calculated the ecosystem services value for these two land types (i.e., forests and farmlands). In any future discussions on regional eco-compensation responsibility, we should also take into account wetlands, sources of drinking water and other land types, in order to assess and calculate regional ecosystem services value and allocation of compensation responsibility. In addition, the allocation of compensation responsibility, among the provincial, municipal and township compensation providers, should be made based on further research on the features associated with the spatial distribution of ecosystem services value in the city.

\section{CONFLICT OF INTEREST}

The authors confirm that this article content has no conflict of interest.

\section{ACKNOWLEDGEMENTS}

Declared none.

\section{REFERENCES}

[1] M. Cai, M. Zeng, and Y. Li, "A Study on the Source of Ecocompensation Fund for the Water Conservation Forest in Miyun Reservoir Upstream," Urban Resources and Environment, no. 4, pp. 61-62, 2013. 
[2] T. Yang, Y. Hu, and K. Zhang, "A Study on the Sources and Utilization of Eco-compensation Fund in Han River Watershed," Journal of Shanxi University of Technology (Social Sciences), vol. 31, no. 2, pp. 56-62, 2013.

[3] S. Engel, S. Pagiola, and S. Wunder, "Designing payments for environmental services in theory and practice: An overview of the issues," Ecological Economics, vol. 65, no. 4, pp. 663 674, 2008.

[4] X. Zhao, W. Li, and X. Wang, "Several Key Issues of Ecological Compensation Research," China Population, Resources and Environment, vol. 22, no. 2, pp. 1-7, 2012.

[5] J. Wang, et al., "Understandings on the Eco-compensation Mechanism and Policies in China," Environmental Protection, no. 10A, pp. 24-28, 2006.

[6] J. Pan, "Main Regional Eco-Compensation and Related Issues - A Case of Beijing and Tianjin Sandstorm Source Region," Journal of HIT(Social Sciences Edition), vol. 16, no. 5, pp. 116-122, 2014.

[7] F. Kong, "Eco-compensation Mechanism for Ecological Function Conservation Zones in the Headwaters - a Case Study of Dongjiang Riverhead Region in Jiangxi Province," Economic Geography, vol. 30, no. 2, pp. 299-305, 2010.

[8] X. Zheng, and X. Han, "Financial Thinking on Establishing Transverse Eco-compensation System," Sub National Fiscal Research, no. 1, pp. 25-29, 2006.

[9] L. Cong, and W. Xu, "Reflections on the Establishment of Basin Ecological Compensation in Fujian Province," Environmental Protection, no. 10A, pp. 29-33, 2006.

[10] Z. Qi, "Research on Our Country's Inter-Regional Ecological Compensation Mechanism: Taking the Ecological Compensation of Watershed of Beijing and Hebei Region as an Example," Ecological Economoic, vol. 30, no. 10, pp. 140-144, 182, 2014

[11] S. Wu, W. Yang, Y. Zhao, and L. Ma, "Innovations and Practice in Water Environment Compensation in Xin'an River Watershed," Environmental Protection, vol. 42, no. 5, pp. 30-33, 2014.

[12] X. Guan, "A Study of the Horizontal Ecological Compensation Mechanism in the Sanjiangyuan Region," Journal of Qinghai Normal University (Philosophy and Social Sciences), no. 6, pp. 14-17, 2008.

[13] Z. Meng, C. Zhu, A. Qu, and Y. Du, "Ecological Compensation of the Major Function Oriented Zoning of China," China Population, Resources and Environment. vol. 18, no. 2, pp. 139-144, 2008.

[14] G. Cao, and D. Jiang, "Ecological Compensation Solution to Transboundary Pollution," Ecological Economy, no. 11, pp. 160-164, 2009.

[15] A. Pang, C. Li, K. Liu, et al. "Ecological Compensation in the Water Source Areas of Zhangweinan Basin Based on Water Environmental Capacity," China Population, Resources and Environment, vol. 20, no. 5, pp. 100-103, 2010.

[16] Y. Lu, Y. Wang, Z. Meng, L. Yu, W. Ding, and Y. Zhao, “A Study on Ecological Compensation Standard of River Basin - A Case Study of Haihe Basin in Henan Province," Journal of Xinyang Normal University (Natural Science Edition), vol. 24, no. 2, pp. 16, 2011.

[17] Y. Fu, B. Ruan, F. Xu, and L. Xu, "Discussion on Ecocompensation Standard of Water Quantity in Yongding River Watershed," Shuili Xuebao, vol. 43, no. 6, pp. 740-748, 2012.

[18] W. Li, J. Xie, J. Li, and H. Shen, "Method of Allocating ecological Compensation Amount of River Basin Based on Improved Shapley Value," System Engineering Theory \& Practice, vol. 33, no. 1, pp. 255-261, 2013.

[19] C. Liu, W. Liu, and M. Xu, “The Provincial Eco-compensation Standard of China Based on Ecological Value Equivalents," Resources Science, vol. 36, no. 1, pp. 148-155, 2014.

[20] X. Yang, Y. Cai, and A. Zhang, "Farmland's Ecological Compensation in Wuhan Metropolitan Area from Prospective of Farmland
Development Restriction," Journal of Huazhong Agricultural University (Social Sciences Edition), no. 4, pp. 92-97, 2014.

[21] G. Yu, J. Geng, P. Zhou, and Z. Li, "Quantitative Research of Regional Ecological Compensation Based on Carbon Balance-Take Zhaoshan Demonstration area of Changzhutan Green Heart as an Example," Resource and Environment in the Yangtze Basin, vol. 21, no. 4, pp. 454-458, 2012

[22] B. A. Babcock, P. G. Lakshminarayan, J. Wu, et al. "Targeting Tools for the Purchase of environmental Amentities," Land Economics, vol. 73, no. 3, pp. 325-339, 1997.

[23] G. V. N. Powell, J. Barborak, and M. Rodriguez, “Assessing Representativeness of Protected Natural Areas in Costa Rica for Protection Biodiversity: A Preliminary Gab Analysis," Biological Conservation, vol. 93, pp. 35-41, 2000.

[24] P. J. Ferrsro, "Conservation Contracting in heterogeneous Landscapes: An Application to watershed protection with threshold constraints," Agricultural and Resource Economics Review, vol. 32, no. 1, pp. 53-64, 2003.

[25] K. M. Chomitz, F. G. A. B. Da, K. Alger, el at. "Viable Reserve Networks Arise from Individual Landholder Responses to Conservation Incentives," Ecology and Society, vol. 11, no. 2, pp. 40, 2006

[26] N. Wang, J. Wu, D. Wu, et al. "Regional Eco-compensation Based on Ecosystem Service Assessment: A Case Study of Shandong Province," Acta Ecological Sinica, vol. 30, no. 23, pp. 6646-6653, 2010

[27] J. Zhong, and W. Mi, "Study on Regional Ecological Compensation Based on Ecosystem Service Value in Ningxia," Journal of Arid Land Resources and Environment, vol. 27, no. 10, pp. 19-24, 2013.

[28] X. Sun, and R. Huang, "Study on Priority Sequence of Regional Ecological Compensation for the Capital City Economic Circle of Anhui Province Based on GIS," Research of Soil and Water Conservation, vol. 20, no. 1, pp. 152-155, 2013.

[29] M. Zhang, H. Cui, C. Liang, et al. "Regional Eco-compensation Based on Ecosystem Service Assessment - a Case of Liaoning Province," Territory \& Natural Resource Study, no. 2, pp. 53-55, 2014.

[30] Y. Jin, T. Huang, and M. Lei, "Study of Ecological Compensation Mechanism in the Process of Western Electricity Sending-off East Application of Three-regional CGE Model," China Industrial Economy, no. 10, pp. 21-28, 2007.

[31] F. Gong, "Study on the Construction and Evolution of the Grassland Ecological Four Compensation Body Model," Journal of Arid Land Resources and Environment, vol. 29, no. 2, pp. 21-26, 2015.

[32] Q. Dai, "On the Status Quo and the Prospect of Eco-compensation Research in China," Chinese Agricultural Science Bulletin, vol. 30, no. 2, pp. 176-182.

[33] R. Costanza, R. d'Arge, R. Groot, S. Farbe, M. Grasso, B. Hannon, K. Limburg, S. Naeem, R. V. O'Neill, J. Paruelo, P. Sutton, and M. Belt, "The value of the world's ecosystem services and natural capital," Nature, vol. 387, pp. 253-260, 1997.

[34] G. Xie, C. Lu, X. Yu, and Z. Du, "The Economic Evaluation of Grassland Ecosystem Services in Qinghai-Tibet Plateau," Journal of Mountain Science, vol. 21, no. 1, pp. 50-55, 2003.

[35] G. Xie, L. Zheng, C. Lu, X. Yu, and C. Cao, “Expert Knowledge Based Valuation Method of Ecosystem Services in China," Journal of Natural Resources, vol. 23, no. 5, pp. 911-919, 2008.

[36] J. Zeng, J. Li, and X. Yao, "Spatio-temporal Dynamics of Ecosystem Service Value in Wuhan Urban Agglomeration," Chinese Journal of Applied Ecology, vol. 25, no. 3, pp. 883-891, 2014.

[37] L. Cheng, F. Li, and F. Hua, "Dynamics of Land Use and Its Ecosystem Services in China's Megacities," Acta Ecologica Sinica, vol. 31, no. 20, pp. 6194-6203, 2011 .

(C) Lixuan et al.; Licensee Bentham Open.

This is an open access article licensed under the terms of the Creative Commons Attribution Non-Commercial License (http://creativecommons.org/licenses/by-nc/3.0/) which permits unrestricted, non-commercial use, distribution and reproduction in any medium, provided the work is properly cited. 